\title{
Penerapan Sistem Merit Dalam Birokrasi Indonesia Untuk Mewujudkan Good Governance
}

\author{
Eviva Nur Khobiburrohma a,1,*, Priska Septiana Margareta ${ }^{b, 2}$, MS. Habbie Hasbullah ${ }^{c, 3}$ \\ 1,2,3 Universitas Muhammadiyah Malang, Indonesia \\ 1 kevivanur@gmail.com, ${ }^{2}$ priskaseptianam@gmail.com, ${ }^{3}$ habbiehasbullah@gmail.com \\ *corresponding author
}

\section{ARTICLE INFO}

\section{Article history}

Received 2020-05-31

Revised 2020-12-22

Accepted 2020-12-30

\section{Keywords}

Merit System, State Civil Apparatus

(ASN), Good Governance

\begin{abstract}
In the current era, countries are required to contribute in order to compete with developing and developed countries. The government provides the legal basis governing the State Civil Apparatus, namely Law No. 5 of 2014. The regulation discusses its relation to the merit system based on qualifications, competencies, and performance. With this regulation, planning in developing human resources is needed in order to improve the quality of personnel themselves. The development of good apparatus resources will benefit an organization. One way can be done by providing education and training for apparatuses to improve their competence and quality. The discussion contained in the regulation of Law No. 5 of 2014 explains the management of human resources in accordance with the regulations.
\end{abstract}

\section{PENDAHULUAN}

System merit berawal pada zaman Dinasti Qin dan Han di China. Pada dinasti ini, system merit dikenalkan melalui pendidikan dan pelatihan kemudian disusul dengan seleksi bagi calon pejabat pemerintahan. Pemerintahan pada Dinasti Qin dan Han menghadapi kesulitan yang kompleks pada jaringan jabatan di pemerintahan hal tersebut karena kekuasaan kerajaan yang begitu luas. Setelah dari China, akhirnya system merit ini berkembang dan menyebar hingga ke British India dan dipergunakan di abad ke-17 kemudian sampai pada daratan Eropa dan Amerika hingga masuk pada negara Indonesia. Di awal kemerdekaan negara Indonesia sampai saat ini telah mengenal dan melaksanakan system merit dalam manajemen pemerintahan terutama pada sistem birokrasi di Indonesia.

Menurut konsep disiplin ilmu system merit ini merupakan suatu system manajemen kepegawaian yang menekankan pada pertimbangan dasar kompetensi bagi calon pejabat Undang-Undang yang berlaku. Kompetensi calon pejabat pemerintah tersebut diartikan bahwa calon pejabat pemerintah harus mempunyai keahlian dan profesionalisme sesuai dengan kebutuhan jabatan yang akan dipangku nantinya. Kompetensi, keahlian dan profesionalistik inilah yang menjadi pertimbangan utuma dalam pegangkatan calon pejabat pemerintah. Sedangkan menurut Merriam-Webster Dictionary system merit adalah system rekrutmen dan promosi pegawai yang dilaksanakan berdasarkan kemampuan dalam melaksanakan tugas, bukan dikarenakan adanya koneksi politik. System merit merupakan kebalikan dari spoil system, yaitu sebuah system dimana jabatan pemerintahan diisi oleh teman-teman, keluarga atau pendukung dari partai yang berkuasa.

Penerapan system merit di Indonesia terutama dalam Manajemen Aparatur Sipil negara telah diamanatkan dalam Undang-Undang No. 5 Tahun 2014 tentang Aparatur Sipil Negara (ASN). Kemudian pada tahun 2017 yang lalu Komisi Aparatur Sipil Negara (KASN) menatapkan Peraturan KASN No. 5 Tahun 2017 tentang Penilaian Mandiri Penerapan Sistem Merit di Instansi Pemerintah. Dalam peraturan tersebut berisi megenai kriteria dan tata cara untuk menilai sejauh mana isntansi pemerintah telah menerapkan system merit dalam Manajemen ASN. Penerapan dari system merit itu sendiri yaitu untuk memastikan bahwa jabatan yang ada di birokrasi pemerintah disusuki oleh pegawai yang memang memenuhi persyaratan kualifikasi dan juga kompetensi. Sehingga tujuan dari pembangunan terutama pada bidang SDM Aparatur untuk mewujudkan ASN yang profesioal, berkinerja tinggi, berintegritas dan menjunjung tinggi netralitas dapat terwujudkan. 
Aparatur Sipil Negara (ASN) merupakan aktor utama dalam penggerak birokrasi pemerintah dalam menyelenggarakan tugas pemerintahan, pembangunan dan pelayanan public. Sehingga untuk menciptkan ASN yang professional, berkinerja tinggi, berintegritas dan netral, pemerintah menetapkan Undang-Undang No. 5 tahun 2014 tentang Aparatur Sipil Negara yang merupakan pergantian dari Undang-Undang No. 8 Tahun 1974 dan Undang-Undang No. 43 Tahun 1999. Undang-Undang No. 5 tahun 2014 ini disusun sebagai program dari reformasi birokrasi yang merupakans ebuah upaya untuk mentrasnformasikan birokrasi pemerintah Indonesia dari rule-based bureaucracy menuju ke dynamic governance. sejalan dengan upaya tersebut, maka manajemen Aparatur Sipil negara juga harus berubah dari administrasi kepegawaian menuju kepembangunan Human Capital.

Penerapan system merit dalam manajemen ASN merupakan salah satu amanat utama yang termatub dalam Undang-Undang No. 5 Tahun 2014. Dimana dengan adanya penerapan dari system merit ini diharapkan pengangkatan pegawai, mutase, promosi, penggajian, penghargaan, dan pengembangan karier dari pegawai itu sendiri didasarkan pada kualifikasi, kompetensi dan kinerja pegawai. Sehingga system tersebut tidak hanya menimbulkan rasa keadilan pada pegawai tetapi juga dapat mendiring peningkatan kompetensi dan juga kinerja dari pegawai tersebut. Untuk menjamin system merit ini dilaksanakan sesuai dengan ketentuan maka dibentuklah Komisi Aparatur Sipil Negara (KASN) untuk melaksanakan pengawasan terhadap pelaksanaan norma dasar ASN, kode etik dan perilaku pegawai ASN.

Berhasil dan tidak berhasilnya penyelenggaraan pemerintahan yang baik ditentukan oleh keterlibatan dan sinergisme antara tiga aktor utama yaitu dari aparatur pemerintah, masyarakat dan private sector. Aparatur pemerintah adalah salah satu aktor penting dalam proses penyelenggaraan pemerintahan dan memegang kendali penuh dalam proses berlangsungnya governance. Dalam mendukung keberhasilan penyelenggaraan pemerintahan, keterlibatan dari aparatur pemerintah ini sangat ditentukan oleh pemahaman terhadap konsep tata pemerintahan yang baik (good governance) serta praktiknya yang terkait dengan birokrasi pemerintah dan manajemen dari birokrasi pemerintah tersebut.

Menurut Sarundajang (2002:164) aparatur adalah suatu komunitas individu-individu yang mempunyai tugas dan fungsi yang terlembagakan untuk melayani rakyat, dimana dapat diartikan bahwa aparatur adalah sebagai pemikir, perencana, pelaksana sekaligus pengawas jalannya kegiatan pemerintahan, pembangunan dan pembinaan kepada masyarakat atas nama kepala daerah. Dilihat dalam konteks tata pemerintahan yang baik, salah satu kunci sukses dari adanya perubahan dalam sebuah proses governance terletak pada individu-individu yang ada dalam proses governance tersebut. Individuindividu ini adalah mereka yang menciptakan serta memelihara perubahan. Wilson \& Rosenfeld (dikutip dalam Sumarto, 2004:11) mengemukakan terdapat 4 (empat) alasan dari kekuatan individu terhadap perubahan yaitu: 1) kepentingan pribadi, 2) rendahnya tingkat kepercayaaan, 3) perbedaan pandangan/peniliain, 4) rendahnya toleransi terhadap perubahan.

Aparatur Sipil Negara atau Aparatur Pemerintahan yang baik adalah ia yang mampu memberikan apa saja yang dibutuhkan oleh masyarakat, bahkan sebelum masyarakat tersebut meminta kepada mereka. Jadi bisa dikatakan bahwa aparatur pemerintahan harus bisa memahami apa saja keinginan dan kebutuhan yang dibutuhkan masyarakat. Dalam keadaan tersebut maka hati nurani dari seorang apartur pemerintahan adalah hati nurani dari masyarakat itu sendiri (Sarundajang, 2002:164). Seperti yang dikemukakan oleh Widodo (2001:32) bahwa seorang aparatur pemerintaha baik di tingkat pusat maupun daerah harus mampu mengubah posisi dan peran dalam memberikan pelayanna publik yaitu dari yang suka mengatur dan memerinyah berubah menjadi suka melayani, dari yang suka menggunakan pendekatan kekuasaan berubah menjadi sika menolong menuju ke arah yang fleksibel, kolaboratis dan dialogis, dan dari cara-cara yang sloganis berubah menuju cara-cara kerja yang realistis pragmatis.

Aparatur secara sempit juga diartikan sebagai Pegawai Negeri Sipil (PNS), yang kemudian gajinya dibebankan pada APBN dan APBD, serta bekerja pada departemen, lemabga pemerintah non departemen, kesekretariatan lembaga tinggi negara, instansi vertikal di daerah provinsi /kabupaten/kota, kepaniteraan pengadilan atau dipekerjakan untuk menyelenggarakan tugas negara lainnya (Sumarto, 2004:11). Sehingga aparatur pemerintahan merupakan pengatur sekaligus pelayan masyarakat yang memberikan pelayanan secara profesional, jujur, adil, dan merata, bekerja secara efektif, efisien dan 
ekonomis dalam rangka menyelenggarakan tugas negara untuk mencapai tujuan dari negara yang konseptual juga ikut serta bertanggung jawab terhadap kesejahteraan dan kepuasan masyarakat sebagai pihak yang diberikan layanan (provider).

Banyak sekali studi yang telah dilakukan oleh beberapa peneliti mengenai manajemen SDM ASN untuk mewujudkan good governance. Salah satunya yaitu studi yang dilakukan oleh Nanang Sampurno \& Agus Wahono (2017) yang menyimpulkan bahwa kompetensi dari Aparatur Sipil Negara (ASN) secara parsial berpengaruh secara signifikan terhadap pelaksanaan good goverance. Begitu juga dengan studi yang dilakukan oleh aldenila Berlianti Akny (2014) yang memberikan kesimpulan bahwa reformasi birokrasi merupakan sarana suatu negara untuk mencapai good governance, dimana dalam reformasi birokrasi hal paling utama adalah dengan melakukan perbaikan pada kualitas SDM aparatur pemerintahnya. Perbaikan system kepegawaian dan pelaksanaan kompenasasi diharapkan mampu meningkatkan performance pegawai agar dapat lebih memaksimalkan lagi pelaksanaan pelayanan dan menjalankan fungsinya sehingga akan terwujud tata pemerintahan yang "good governance".

Oleh karena itu, ketika seorang aparatur telah memiliki pemahaman yang inklusif dia ia memegang teguh prinsip-prinsip good governance secara konsekuen maka tentunya akan berpengaruh terhadap terwujudnya pemerintahan yang baik dan bersih. Good governance sendiri dilandasi oleh 3 (tiga) pilar utana yaitu akuntabilitas, transaparansi keuangan dan partisipasi politik. Untuk mencapai kinerja yang baik itulah maka diperlukan dukungan Sumber Daya Manusia (SDM) yang berkualitas.

Berdasarkan uraian latar belakang tersebut maka tulisan ini akan berusaha membahas mengenai bagaimana penerapan dari system merit untuk mewujudkan tata pemerintahan yang baik atau good governance. Tidak semua prinsip-prinsip good governance akan dipaparkan dalam tulisan ini, tetapi dibatasi 3 (tiga) parameter saja yaitu akuntabilitas, transparansi dan partisipasi masyarakat.

\section{LANDASAN TEORI}

\section{Sistem Merit Dalam Kebijakan dan Manajemen ASN}

Landasan Hukum Penerapan sistem merit di birokrasi pemerintah Indonesia didasarkan pada peraturan perundang-undangan sebagai berikut:

1. Undang-Undang Nomor 5 Tahun 2014 tentang Aparatur Sipil Negara (ASN);

2. Peraturan Presiden Nomor 11 Tahun 2017 tentang Manajemen Pegawai Negeri Sipil (PNS);

3. Peraturan Menteri Pendayagunaan Aparatur Negara dan Reformasi Birokrasi Nomor 40 Tahun 2018 tentang Pedoman Sistem Merit dalam Manajemen Aparatur Sipil Negara (ASN);

4. Peraturan Ketua Komisi Aparatur Sipil Negara Nomor 5 Tahun 2017 tentang Penilaian Mandiri Penerapan Sistem Merit dalam Manajemen Aparatur Sipil Negara (ASN) di Instansi Pemerintah

\section{Pengertian, Tujuan dan Prinsip}

Sistem merit, menurut Pasal 1 Undang-Undang No. 5 tahun 2014, adalah kebijakan dan manajemen ASN yang berdasarkan pada kualifikasi, kompetensi, dan kinerja secara adil dan wajar dengan tanpa membedakan latar belakang politik, ras, warna kulit, agama, asal usul, jenis kelamin, status pernikahan, umur, atau kondisi kecacatan. Tujuan penerapan sistem merit dalam manajemen ASN sebagai berikut:

1. Melakukan rekrutmen, seleksi, dan promosi berdasarkan kompetensi yang terbuka dan adil dengan menyusun perencanaan SDM Aparatur secara berkelanjutan;

2. Memperlakukan pegawai ASN secara adil dan setara;

3. Mengelola pegawai ASN secara efektif dan efisien;

4. Memberikan remunerasi yang setara untuk pekerjaan-pekerjaan yang setara dengan memperhatikan hasil kinerja;

5. Memberikan penghargaan atas kinerja pegawai yang tinggi; f. Memberikan hukuman atas pelanggaran disiplin;

6. Menjaga standar yang tinggi untuk integritas, perilaku, dan kepedulian untuk kepentingan masyarakat;

7. Menerapkan pengisian jabatan dengan uji kompetensi sesuai standar kompetensi jabatan yang dipersyaratkan; 
8. Memberikan kesempatan untuk mengembangkan kompetensi kepada pegawai ASN;

9. Melaksanakan manajemen kinerja pegawai untuk mencapai tujuan organisasi;

10. Melindungi pegawai ASN dari intervensi politik dan tindakan kesewenang-wenangan;

11.Memberikan perlindungan kepada pegawai.

Untuk melaksanakan kebijakan sebagaimana disebutkan di atas, Peraturan Pemerintah No. 11 Tahun 2017 menetapkan prinsip merit sebagai berikut:

1. Seluruh jabatan sudah memiliki standar kompetensi jabatan;

2. Perencanaan kebutuhan pegawai sesuai dengan beban kerja;

3. Pelaksanaan seleksi dan promosi dilakukan secara terbuka;

4. Memiliki manajemen karier yang terdiri dari perencanaan, pengembangan, pola karier, dan rencana suksesi yang diperoleh dari manajemen talenta;

5. Memberikan penghargaan dan mengenakan sanksi berdasarkan pada penilaian kinerja yang objektif dan transparan;

6. Menerapkan kode etik dan kode perilaku pegawai ASN;

7. Merencanakan dan memberikan kesempatan pengembangan kompetensi sesuai hasil penilaian kinerja;

8. Memberikan perlindungan kepada pegawai ASN dari tindakan penyalahgunaan wewenang; dan

9. Memiliki sistem informasi berbasis kompetensi yang terintegrasi dan dapat diakses oleh seluruh pegawai ASN.

\section{Komisi Aparatur Sipil Negara sebagai Pengawas Sistem Merit}

KASN (Komisi Aparatur Sipil Negara) adalah lembaga non-struktural yang mandiri dan bebas dari intervensi politik yang berfungsi mengawasi penerapan nilai dasar, kode etik dan kode perilaku serta penerapan sistem merit. Untuk memastikan sistem merit diterapkan di instansi Pemerintah, KASN diberi kewenangan mengawasi setiap tahap pelaksanaan pengisian JPT melalui seleksi terbuka. Pengawasan dilakukan:

1. secara preventif: melalui sosialisasi tata cara seleksi dan penerbitan rekomendasi terhadap pelaksanaan dan hasil seleksi; serta

2. secara represif: dengan menindaklanjuti pengaduan masyarakat atas dugaan terjadi pelanggaran dalam pelaksanaan pengisian JPT dan menerbitkan rekomendasi berdasarkan hasil investigasi.

Disamping itu, Pasal 111 UU ASN memberi KASN kewenangan untuk menetapkan apakah suatu instansi sudah menerapkan sistem merit sehingga dapat dikecualikan dari seleksi terbuka dalam pengisian JPT. KASN juga membina instansi pemerintah dalam mengembangkan manajemen ASN yang berbasis sistem merit.

\section{a. Pengertian Aparatur Sipil Negara (ASN)}

Aparatur Sipil Negara (ASN) adalah perubahan dari yang sebelumnya dikenal dengan Pegawai Negeri Sipil (PNS). Pengertian ASN berdasarkan Undang-Undang Republik Indonesia Nomor 5 Tahun 2014 Tentang Aparatur Sipil Negara (UU ASN) pada Pasal 1 Ayat (1), disebutkan bahwa Aparatur Sipil Negara selanjutnya disingkat ASN adalah profesi bagi pegawai negeri sipil dan pegawai pemerintah dengan perjanjian kerja yang bekerja pada instansi pemerintah. Dilanjutkan pada Pasal 1 Ayat (2), ASN atau pegawai negeri sipil dan pegawai pemerintah dengan perjanjian kerja yang diangkat oleh pejabat pembina kepegawaian dan diserahi tugas dalam suatu jabatan pemerintahan atau diserahi tugas negara lainnya dan digaji berdasarkan peraturan perundang-undangan. Adapun dijelaskan kembali pada Pasal 1 Ayat (3), bahwa ASN adalah profesi bagi pegawai negeri sipil dan pegawai pemerintah dengan perjanjian kerja yang bekerja pada instansi pemerintah. Sementara itu jika dilihat pada Pasal 1 Ayat (4), Pegawai Pemerintah dengan Perjanjian Kerja yang selanjutnya disingkat PPPK adalah warga negara Indonesia yang memenuhi syarat tertentu, yang diangkat berdasarkan perjanjian kerja untuk jangka waktu tertentu dalam rangka melaksanakan tugas pemerintahan.

Berdasarkan Undang- undang Nomor 5 Tahun 2014, eksistensi Pegawai ASN berfungsi sebagai pelaksana kebijakan publik yg dibuat pejabat pembina; pelayan Publik yang berkualitas dan profesional; dan perekat dan pemersatu bangsa. Terbitnya UU ASN tersebut juga sebagai 
tombak perubahankepegawaian yang mampu meningkatkan kualitas birokrasi. Hal itu bisa dilihat dari rekrutmen yang dilakukan harus bisa mengontrol belanja pegawai, penempatan pegawai yang memiliki integritas untuk mengurangi kebocoran anggaran, penempatan pegawai yang berdasarkan kompetensi yang dibutuhkanuntuk menjamin pencapaian kinerja. Sehingga anggaran negara dapat digunakan sebesar-besarnya untuk pembangunan dan belanja publik, secara efektif dan efisien. Tujuan utama UU ASN ini antara lain yaitu independensi dan netralitas, kompetensi, kinerja/produktivitas kerja, integritas, kesejahteraan, kualitas pelayanan publik, serta pengawasan dan akuntabilitas. Prinsip dasar UU ASN adalah memberlakukan "Sistem Merit". Dimana Sistem merit ini adalah kebijakan dan manajemen ASN yang berdasarkan pada kualifikasi, kompetensi, dan kinerja, secara adil dan wajar dengan tanpa membedakan latar belakang, politik, ras, warna kulit, agama, asal usul jenis kelamin, status pernikahan, umur ataupun kondisi kecacatan. Sistem Merit dilakukan ini dilakukan dengan seleksi dan promosi secara adil dan kompetitif, menerapkan prinsip keadilan, penggajian, reward and punishment berbasis kinerja, standar integritas dan perilaku untuk kepentingan publik, manajemen SDM secara efektif dan efisien dan melindungi pegawai dari intervensi politik dan dari tindakan semena-mena.

\section{b. Pengertian Good Governance}

Berdasarkan United Nation Development Program (UNDP: 2004), tata kelola pemerintahan yang baik adalah:"Penggunaan wewenang ekonomi politik dan administrasi untuk mengelola berbagai urusan negara pada setiap tingkatannya dan merupakan instrumen kebijakan negara untuk mendorong terciptanya kondisi kesejahteraan integritas, dan kohesivitas sosial dalam masyarakat". Sedangkan Koiman (2009:273) mengemukakan bahwa governance adalah serangkaian proses interaksi sosial politik antara pemerintah dengan masyarakat dalam berbagai bidang yang berkaitan dengan kepentingan masyarakat dan intervensi pemerintah atas kepentingan-kepentingan tersebut. Governance merupakan mekanisme-mekanisme, prosesproses dan institusi-institusi melalui warga Negara yang mengartikulasi kepentingan-kepentingan mereka, memediasi perbedaan-perbedaan mereka serta menggunakan hak dan kewajiban legal mereka.

Dari beberapa pengertian diatas dapat disimpulkan bahwa good governance adalah sebuah tata pemerintahan, dimana terdapat penggunaan wewenang ekonomi, politik, dan administrasi guna mengelola urusan-urusan negara pada semua tingkatan.Tata pemerintahan tersebut mencakup seluruh proses mekanisme dan lembaga-lembaga yang mana terdapat warga dan kelompok-kelompok masyarakat yang salin mengutarakan kepentingan mereka, dengan menggunakan hak-hak yang berdasarkan hukum, memenuhi semua kewajiban dan menjembatani perbedaan-perbedaan diantara mereka.

\section{Prinsip-Prinsip Good Governance}

1. Akuntabilitas

Akuntabilitas adalah bentuk pertangungjawaban pejabat publik terhadap masyarakat yang memberinya kewenangan untuk mengurusi kepentingan mereka. Bentuk pertanggungjawaban tersebut berbeda satu dengan lainnya tergantung dari jenis organisasi yang bersangkutan. Instrumen dasar akuntabilitas adalah peraturan perundang-undangan yang ada, dengan komitmen politik akan akuntabilitas maupun mekanisme pertanggungjawaban, sedangkan instrumeninstrumen pendukungnya adalah pedoman tingkah laku dan sistem pemantauan kinerja penyelenggara pemerintahan dan sistem pengawasan dengan sanksi yang jelas dan tegas.

2. Transparansi

Transparansi adalah keterbukaan atas semua tindakan dan kebijakan yang diambil oleh pemerintah. Prinsip transparansi menciptakan kepercayaan timbal-balik antara pemerintah dan masyarakat melalui penyediaan informasi dan menjamin kemudahan di dalam memperoleh informasi yang akurat dan memadai. Tranparansi dibangun atas dasar arus informasi yang bebas. Seluruh proses pemerintahan, lembaga-lembaga dan informasi perlu dapat diakses oleh pihakpihak yang berkepentingan, dan informasi yang tersedia harus memadai agar dapat dimengerti dan dipantau. Sehingga bertambahnya wawasan dan pengetahuan masyarakat terhadap penyelenggaraan pemerintahan.

3. Partisipasi Masyarakat 
Semua warga masyarakat mempunyai suara dalam pengambilan keputusan, baik secara langsung maupun melalui lembaga-lembaga perwakilan sah yang mewakili kepentingan mereka. Partisipasi bermaksud untuk menjamin agar setiap kebijakan yang diambil mencerminkan aspirasi masyarakat. Bentuk lain untuk merangsang keterlibatan masyarakat adalah melalui perencanaan partisipatif untuk menyiapkan agenda pembangunan, pemantauan, evaluasi dan pengawasan secara partisipatif dan mekanisme konsultasi untuk menyelesaikan isu sektoral.

\section{METODE PENELITIAN}

Dalam penulisan artikel ini penulis menggunakan pendekatan kualitatif yaitu dengan harapan penulis mampu mengkaji dan menjelaskan mengenai penerapan system merit di Indonesia dalam mewujudkan good governance. Penelitian ini merupakan penelitian deskriptif yang mana penulis hanya menggambarkan konsep dan juga teori yang dikaji selama melakukan penelitian mengenai penerapan system merit di Indonesia dalam mewujudkan good governance.

Untuk mendukung penulis dalam mengkaji fenomena tersebut, dalam penelitian ini penulis menggunakan studi kepustakaan dalam mengumpulkan data-data yang relevan melalui berbagai sumber terpercaya baik melalui buku, jurnal, artikel di media massa dan juga di internet. Sebagaimana di kemukakan oleh Miles \& Huberman (1992) dalam Abas (2017:80) terdapat empat tahapan analisis data yaitu pengumpulan data, reduksi data, penyajian data dan penarikan kesimpulan secara induktif dimana penulis juga akan melakukan tahap tersebut dalam data penelitian ini.

\section{HASIL DAN PEMBAHASAN}

Menurut Pasal 1 Undang-Undang No. 5 Tahun 2014, system merit adalah sebuah kebijakan dan manajemen Aparatur Sipil negara (ASN) yang berdasarkan pada kualifikasi, kompetensi, dan kinerja secara adil dan wajar dengan tanpa membelakangi latar belakang politik, ras, warna kulit, agama, asalusul, jenis kelamin, status pernikahan, umur atau kondisi kecacatan tertentu. Tujuan dari adanya penerapan system merit di Indonesia yaitu:

1) Melakukan recruitmen, seleksi dan promosi jabatan yang didasarkan pada kompetensi yang terbuka dan adil dengan menyusun perencanaan sumber daya manusia (SDM) aparatur secara berkelanjutan.

2) Memberikan perlakuan yang adil dan setara kepada seluruh pegawai ASN

3) Memberikan pengelolaan yang efektif dan efisien kepada pegawai ASN

4) Memberikan remunerasi yang setara untuk pekerjaan yang setara dengan tetap memperhatikan hasil kinerja

5) Memberikan penghargaan kepada kinerja pegawai yang tinggi

6) Memberikan hukuman atau punishment atas pelanggaran disiplin

7) Menjaga standart tinggi untuk integritas, etika dan kepedulian untuk kepentingan masyarakat

8) Menerapkan pengisian jabatan dengan uji kompetensi sesuai dengan standart kompetensi jabatan yang dipersyaratkan

9) Memberikan kesempatan untuk mengembangkan kompetensi kepada pegawai ASN

10) Melaksanakan manajemen kinerja pegawai untuk mencapai tujuan organisasi

11) Memberikan perlindukan kepada pagawai ASN dari intervensi politik dan tindakan kesewenang-wenangan.

Ada beberapa alasan mengapa Indonesia menerapkan system merit dalam penyelenggaraan pemerintahan. Hal tersebut karena berdasarkan Undang-Undang No. 5 Tahun 2014 tentang Aparatur Sipil negara (ASN) telah mengamanatkan bahwa penerapan system merit dalam kebijakan dan manajemen ASN. 
Grafik 1. Peta Penerapan Sistem Merit Manajemen ASN dibeberapa Kementrian tahun 2018

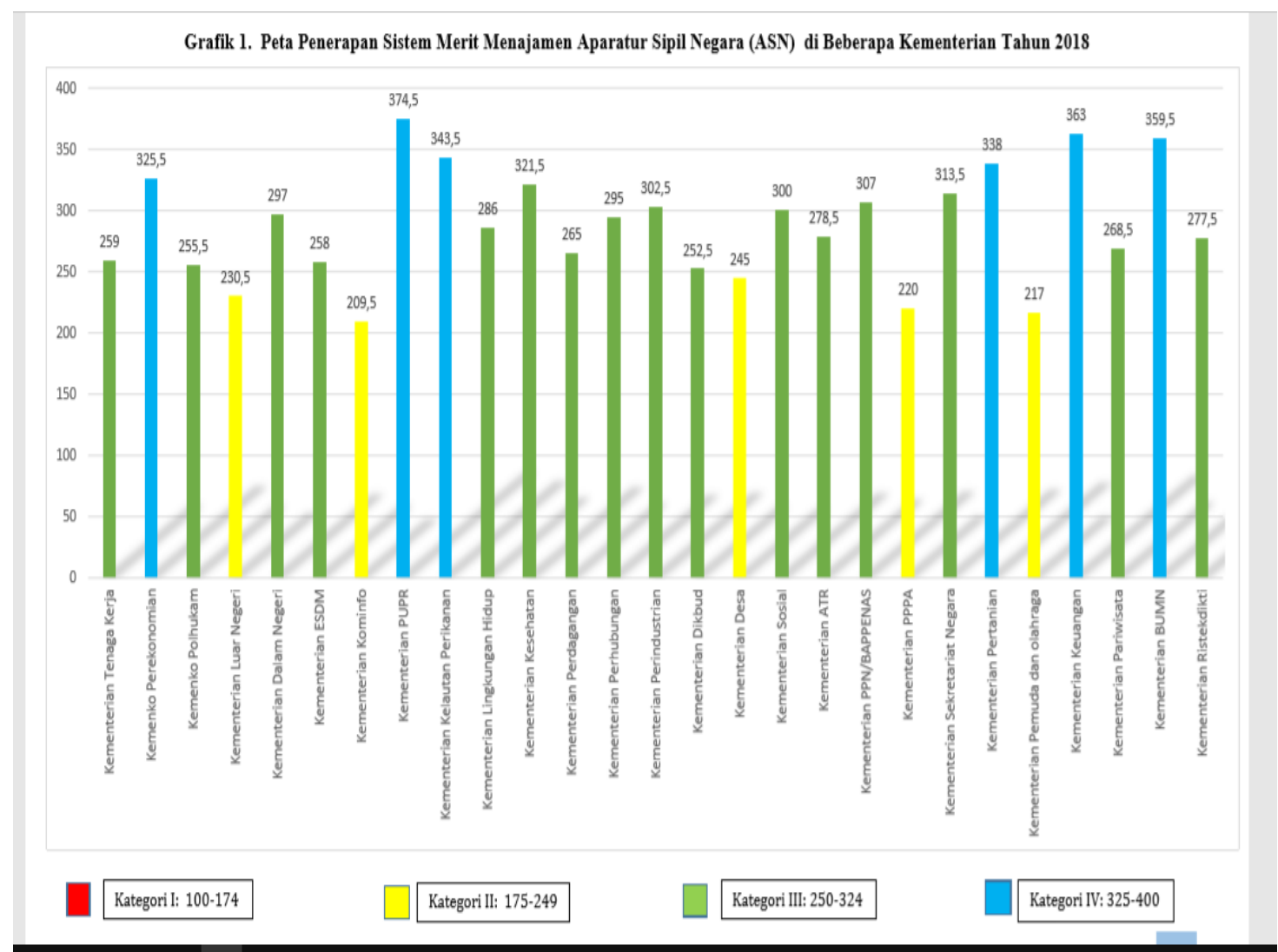

Grafik 1 menunjukkan hasil penilaian tingkat penerapan sistem merit di Kementerian. Adapun hasilnya sebagai berikut:

a. Terdapat 6 (enam) kementerian yang masuk dalam kategori IV "Sangat Baik" yaitu Kementerian Koordinator Bidang Perekonomian, Kementerian Pekerjaan Umum dan Perumahan Rakyat, Kementerian Kelautan dan Perikanan, Kementerian Pertanian, Kementerian Keuangan, dan Kementerian BUMN.

b. Terdapat 16 (enam belas) kementerian yang masuk dalam kategori III "Baik" yaitu

Kementerian Tenaga Kerja, Kementerian Koordinator Bidang Politik, hukum dan Keamanan, Kementerian Dalam Negeri, Kementerian Energi dan Sumber Daya Mineral, Kementerian Lingkungan Hidup, Kementerian Kesehatan, Kementerian Perdagangan, Kementerian Perhubungan, Kementerian Perindustrian, Kementerian Pendidikan dan Kebudayaan, Kementerian Sosial, Kementerian Agraria dan Tata Ruang, Kementerian Perencanaan dan Pembangunan Nasional, Kementerian Sekretariat Negara, Kementerian Pariwisata dan Kementerian Riset, Teknologi, dan Pendidikan Tinggi.

c. Terdapat 5 (lima) kementerian yang masuk dalam kategori II "Kurang" yaitu Kementerian Luar Negeri, Kementerian Komunikasi dan Informatika, Kementerian Desa, Kementerian Pemberdayaan Perempuan dan Perlindungan Anak serta Kementerian Pemuda dan Olahraga.

Berdasarkan data tersebut sebagian besar kementerian masuk dalam kategori III, dan tidak ada kementerian yang masuk dalam kategori I. Kondisi ini menggambarkan bahwa kementerian sudah menerapkan sistem merit namun masih perlu menyempurnakan berbagai persyaratan penerapan sistem merit dalam manajemen ASN, terutama terkait pembangunan talent pool dan rencana suksesi yang didukung oleh program pembinaan karier untuk memastikan para calon pimpinan ke depan memenuhi persyaratan yang telah ditetapkan. 
Grafik 2. Peta Penerapan Sistem Merit Manajemen ASN dibeberapa Kementrian tahun 2018

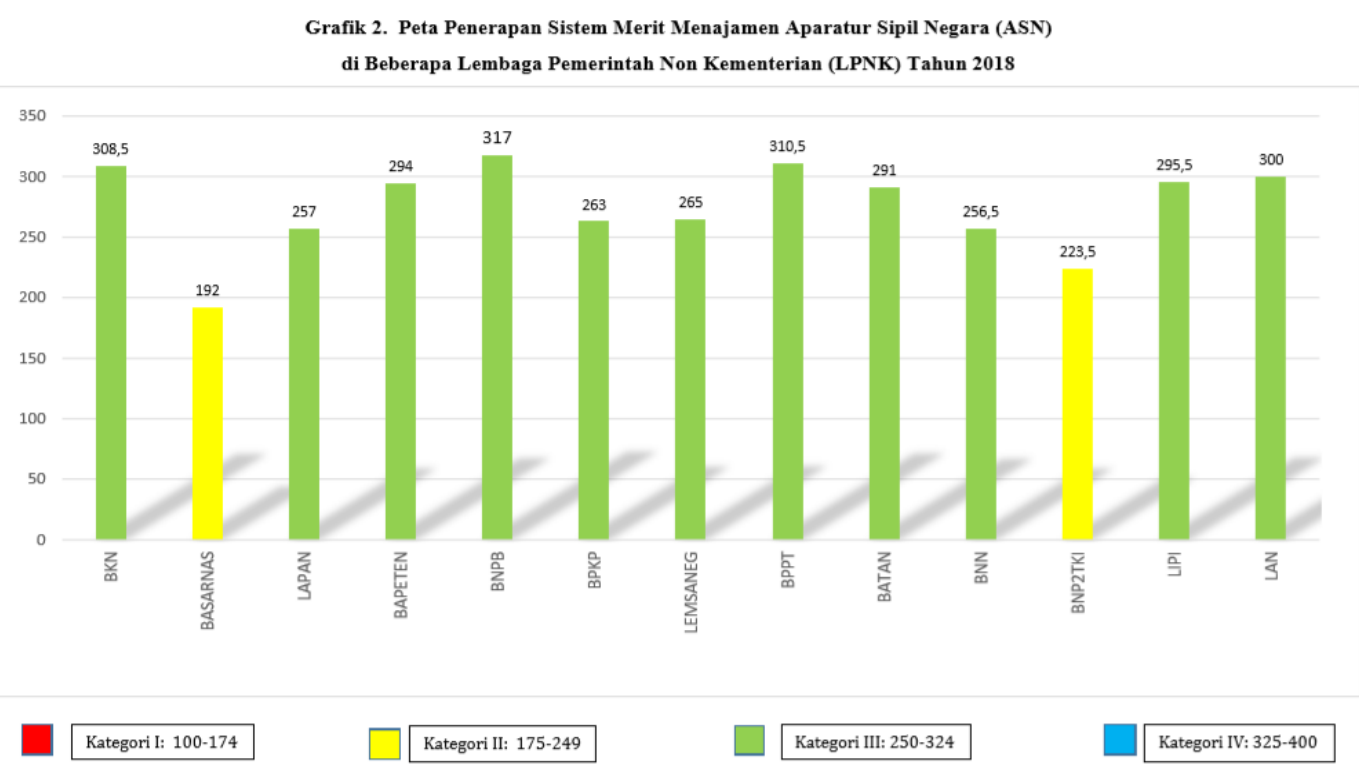

Grafik 2 menunjukkan bahwa dari beberapa Lembaga Pemerintah Non Kementeria (LPNK) yang telah melakukan penilaian mandiri penerapan sistem merit, sebagai berikut:

a. Terdapat 11 (sebelas) instansi masuk dalam kategori III "Baik" yaitu Badan Kepegawaian Negara (BKN), Lembaga Penerbangan dan Antariksa Nasional (LAPAN), Badan Pengawas Tenaga Nuklir (BAPETEN), Badan Pengawas Keuangan dan Pembangunan (BPKP), Badan Nasional Penanggulangan Bencana (BNPB), Badan Siber dan Sandi Negara (Lemsaneg), Badan Pengkajian dan Penerapan Teknologi (BPPT), Badan Tenaga Nuklir (BATAN), Badan Narkotika Nasional (BNN), Lembaga Ilmu Pengetahuan Indonesia (LIPI), serta Lembaga Administrasi Negara (LAN);

b. Terdapat 2 (dua) instansi masuk dalam kategori II "Kurang" yaitu Badan Nasional Pencarian dan Pertolongan (BASARNAS) dan Badan Nasional Penempatan dan Perlindungan Tenaga Kerja Indonesia (BNP2TKI).

Grafik 3. Peta Penerapan Sistem Merit Manajemen ASN dibeberapa Kementrian tahun 2018

Grafik 3. Peta Penerapan Sistem Merit Menajamen Aparatur Sipil Negara (ASN) di Pemerintah Provinsi Tahun 2018

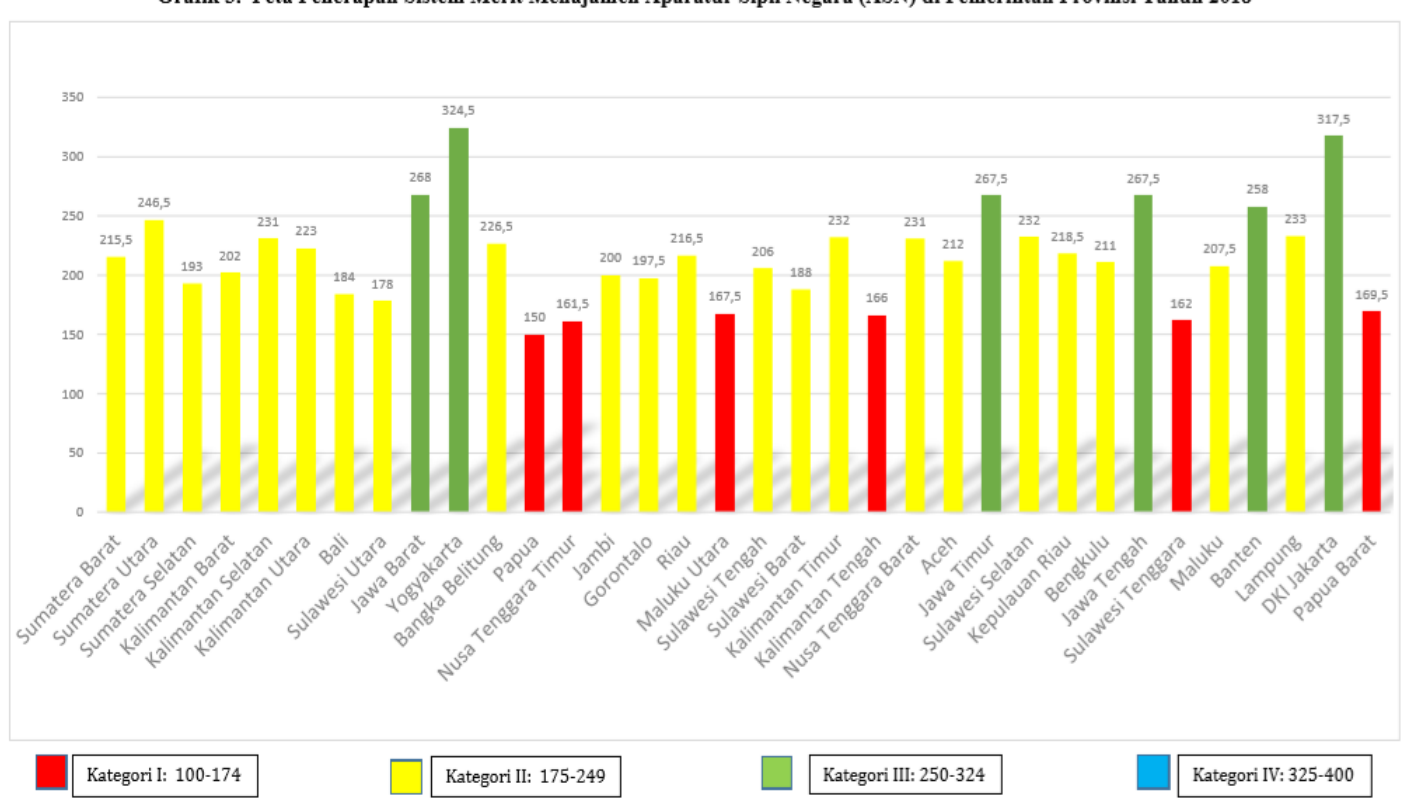


Grafik 3 menunjukkan dari Pemerintah Provinsi yang telah melakukan penilaian mandiri penerapan sistem merit, didapatkan hasil sebagai berikut:

a. Terdapat 6 (enam) Provinsi masuk dalam kategori III "Baik" yaitu Jawa Barat, Daerah Istimewa Yogyakarta, Jawa Timur, Jawa Tengah, Banten, dan DKI Jakarta.

b. Terdapat 22 (dua puluh dua) Provinsi masuk dalam kategori II "Kurang" yaitu Sumatera Barat, Sumatera Utara, Sumatera Selatan, Kalimantan Utara, Bali, Sulawesi Utara, Bangka Belitung, Jambi, Gorontalo, Riau, Sulawesi Tengah, Sulawesi Barat, Kalimantan Timur, Nusa Tenggara Barat, Aceh, Kepulauan Riau, Kalimantan Barat, Kalimantan Selatan, Sulawesi Selatan, Bengkulu, Maluku dan Lampung.

c. Terdapat 6 (enam) Provinsi yang masuk dalam kategori I "Buruk" yaitu Papua, Nusa Tenggara Timur, Kalimantan Tengah, Sulawesi Tenggara, Maluku Utara, dan Papua Barat.

Sebagian besar Provinsi masuk dalam kategori II "Kurang", dan tidak ada Provinsi yang masuk dalam kategori IV "Sangat Baik". Kondisi ini menggambarkan bahwa Pemerintah Provinsi belum menerapkan sistem merit, terutama beberapa Provinsi di bagian Indonesia Timur (Kategori I). Indonesia bagian tengah dan pulau sumatera masuk dalam kategori II, sedangkan pemerintah provinsi yang masuk dalam kategori III "Baik" berada di pulau Jawa. Hal ini disebabkan oleh beberapa faktor diantaranya yaitu, kemampuan daerah dalam menerapkan sistem merit baik dari segi sumber daya manusia, anggaran, fasilitas pendukung yang masih terbatas, dan pemahaman mengenai penerapan sistem merit itu sendiri yang berbeda-beda. Selain itu, penerapan sistem merit di Pemerintah Provinsi ini masih kurang didukung oleh kepala daerah dan intervensi politik yang cukup kuat.

\section{KESIMPULAN}

Penerapan sistem merit di instansi pemerintah sudah merupakan sesuatu yang "urgent", sebagai upaya untuk mewujudkan ASN yang profesional, guna mendukung tercapainya tujuan reformasi birokrasi, yaitu birokrasi yang efektif dan efisien, serta melayani. Perubahan yang cepat secara global harus diantisipasi oleh Pemerintah dengan membangun human capital di sektor pemerintahan agar Indonesia mampu bersaing di tingkat global.

Hasil pemetaan penerapan sistem merit dalam manajemen ASN yang telah dilakukan KASN di seluruh Kementerian, LPNK dan Pemerintah Provinsi menunjukkan bahwa belum banyak instansi yang siap untuk menerapkan sistem merit. Berbagai prasyarat masih perlu disiapkan, namun instansi dihadapkan pada keterbatasan dana dan pengalaman dalam mengembangkan sistem merit. Komitmen yang tinggi dari pimpinan instansi sangat diperlukan dalam mewujudkan manajemen ASN yang berbasis merit.

\section{Saran}

Aparatur Sipil Negara (ASN) kurang bertindak tidak sesuai hal ini dikarenakan minimnya ilmu yang dimiliki sebagaimana instansi ia bekerja sehingga berpengaruh pada proses penyelenggaraan proses layanan publik tugas pemerintahan dan tugas pembangunan untuk itu pemerintah perlu melakukan hal sebagai berikut:

a. Menyediakan peraturan perundang-undangan yang diperlukan bagi pelaksanaan Undang-Undang ASN, khususnya yang terkait dengan Pangkat dan Jabatan, Pedoman Pola Karier, dan lain-lain;

b. Mendorong dan membina Instansi Pemerintah yang tingkat penerapan sistem merit dalam Manajemen ASN nya masih belum baik untuk meningkatkan penerapan sistem meritnya ke kategori yang lebih baik ke depan;

c. Melakukan akreditasi terhadap assessment center dan sertifikasi assesor;

d. Menyempurnakan peraturan perundang-undangan terkait manajemen kinerja dan membina pelaksanaannya agar penilaian kinerja lebih terukur dan obyektif;

e. Menyiapkan peraturan dan pedoman terkait penyusunan strategi dan program diklat yang didasarkan pada kesenjangan kompetensi dan kinerja; 


\section{DAFTAR PUSTAKA}

Andi, M. S. (2017). Implementasi Peningkatan Kinerja melalui Merit Sistem guna Melaksanakan Undang-Undang Aparatur Sipil Negara No. 5 Tahun 2014 di Kementerian Hukum dan HAM (Performance Improvement By Merit System Under The Act Of Civil State . Implementasi Peningkatan Kinerja Melalui Merit Sistem Guna Melaksanakan Undang-Undang Aparatur Sipil Negara No. 5 Tahun 2014 Di Kementerian Hukum dan HAM (Performance Improvement By Merit System Under The Act Of Civil State Jurnal, 185-186.

Atik, M. (2010). Analisis Reormasi Birokrasi Di Badan Kepegawaian Provinsi Jawa Timur. Analisis Reormasi Birokrasi Di Badan Kepegawaian Provinsi Jawa Timur, 56-59.

Daryanto, A. (2015). Merit System Dalam Manajemen Pegawai Negeri Sipil. Merit System Dalam Manajemen Pegawai Negeri Sipil. Civil Service Journal, 20-25.

Goebel, Z. (2020). Global Leadership Talk: Constructing Good Governance In Indonesia. Global Leadership Talk: Constructing Good Governance In Indonesia Journal, 123-124.

Ismail, N. (2019). Merit Sistem dalam Mewujudkan Transparansi Pembinaan Karier Aparatur Sipil Negara. Merit System dalam Mewujudkan Transparansi Pembinaan Karier Aparatur Sipil Negara Jurnal, 35.

Kharisma, B. R. (2016). Aparatur Sipil Negara. Jakarta: Kencana.

Nder, H. H. (2014). Ketidaknetralan Birokrasi Di Indonesia. Jakarta: Elex Media Komputindo.

Noors, A., \& Indonesia., I. A. (2019). Analisis Pelaksanaan Seleksi Terbuka Bagi Pengisian Jabatan Pimpinan Tinggi Di Indonesia. Analisis Pelaksanaan Seleksi Terbuka Bagi Pengisian Jabatan Pimpinan Tinggi Di Indonesia Journal, 53.

PANGESTUTI, E. (2019). Analisis Pemanfaatan Hasil Talent Pool Aparatur Sipil Negara Di Indonesia. Analisis Pemanfaatan Hasil Talent Pool Aparatur Sipil Negara Di Indonesia Journal, 56.

Pemerintahan Republik Indonesia. (2016). Aparatur Sipil Negara. Pemerintah Republik. "UndangUndang Republik Indonesia Nomor 5 Tahun 2014 Tentang Aparatur Sipil Negara., 30-32.

Warren, C. L. (2016). Human Ecolog. The Local Turn: An Introductory Essay Revisiting Leadership, Elite Capture And Good Governance In Indonesian Conservation And Development Programs, 277-286. 